\title{
BUZZ MARKETING AS AN EFFECTIVE TOOL TO SUPPORT INFORMATION PROCESSES IN AN ENTERPRISE LOCATED AT THE RURAL AREA
}

\author{
Nicoletta Baskiewicz, Ewa Kempa \\ Czestochowa University of Technology, Poland
}

\begin{abstract}
Thea aim of this article is to present the phenomenon of buzz marketing as an effective tool supporting the information process in an enterprise located in a rural area. Information, both in- and output, is considered a key asset determining the competitiveness of the enterprise. Having in mind the commonly acknowledged and still actual norms of behavior, the authors suggest that buzz marketing may play an important role in passing information between the enterprises and its environment in $r$.
\end{abstract}

Keywords: buzz marketing, information, information processes, information channels

DOI: $10.17512 /$ znpcz.2016.1.02

\section{Introduction}

The operation of a modern enterprise should be based on an effective management of information, which is considered not only a valuable asset of the company, but even a factor that integrates internal and external activities of the enterprise, including marketing activities. Moreover, it should be noted that information is also an integral part and foundation of management. Because management is a continuous process, information plays a vital role in formulating the enterprise itself, and later its strategic and operational goals (Moszkowicz, 2005, p. 312). Information should be defined as a set of data (numbers, facts), that went through mental processing. Gathered information form strategies in global and functional dimensions; on the other hand, their conscious distribution from the enterprise through varied channels help tighten the bond between the enterprise and its customers: both current and potential.

\section{Information as an essential asset of the operation of enterprise}

Information is considered a key asset of current enterprises, and modern economy is commonly referred to as "knowledge based", which is determined by the effectiveness of gathering, transforming and adapting information. Information should be distinguished from data, which is defined by raw, unanalyzed facts, numbers and events, that can be transformed into information, e.g. level of stock. Therefore information is analyzed or processed data which inform the recipient of the situation (Stoner, Wankel 1996, p. 477). The process of data interpretation requires specified knowledge of the described world and language in which the data are written. Knowledge plays an active role in data interpretation, as it gives the data meaning (sense). By drawing conclusions from received information and possessed knowledge, with own experience and skills, we attach the information to our knowledge, transforming it or creating new knowledge. Thus: 


\section{New knowledge $=$ information + context $($ held knowledge $)+$ experience in transforming knowledge (information)}

(http://www.inzynieriawiedzy.pl/wiedza/wiedza-informacje-dane, odczyt: 24 stycznia 2016)

This "definition" shows that creating new knowledge is realized in a given cognitive context, i.e. in the field of possessed knowledge, used to "interpret" examined information, which broaden or modify possessed knowledge.

Knowledge management, and hence information management, currently became a factor determining competitive advantage. "The challenges of modern, globalized landscape of competition are making the use of knowledge necessary in all processes and levels of enterprise operation, hence the requirement of rational knowledge management translates to tasks and desired characteristics of almost all components of competitiveness potential" (Stankiewicz 2002, p. 229). It is worth noting, that currently the problem is not the difficulty of gathering the information, but the skill of choice of the information required in the aspect of specified needs, because of the information overflow. It is widely recognized that in the choice of information, following parameters should be evaluated: quality, topicality, volume, relevance to tasks.

We can view information management in the aspect of three areas of their acquiring, direction of provision, and place of use:

1) valuating and acquiring data from the outside and their transformation into information relevant to enterprise development (information from suppliers, customers, contractors, competitors, used for optimization of decision process and the quality of decisions);

2) creating databases and gathering information in the enterprise itself, for the use of the enterprise (information on effectiveness of production processes, employees, optimal workload of machines and devices);

3) communicating information outside the enterprise (all informational activities, including advertising and recruitment, information on sales promotions, quality of services).

In literature, the processes of information transformation into knowledge are widely written about. In this study assumes that the process of creating knowledge from information consists of the following stages: information, interpretation and study of their usefulness, integration in the collection, location in the database, obtain and match information to the situation and application. Between the usage and collection of information there also combinations, which can cause the whole process to start again based on new information regarding their previous usage. It is noted in this process that the phase of obtaining and fitting is the action, which has a goal of transferring information into knowledge. In the process of thought are integrated collections of information then followed by questions being asked, seeking answers to formulate opinions (Mikuła, Ćwikliński 2001). Additionally, through careful management of knowledge, which undoubtedly arises from the information also stimulates the development of procedural competence of team members. M. Sarvary distinguishes three knowledge management subprocesses, in which information plays a key role (Sarvary 1999): 
- organisational learning - the process of gathering information and/or knowledge,

- creating knowledge - a process of transformation and integration of information into knowledge, making them useful in solving business problems,

- distribution of knowledge - a process that gives members access to knowledge organization and allows it to use.

Modern conditions determine the necessity of acquiring knowledge by the company in a particular place and time so that it can operate efficiently and can be competitive in the market. The real revolution in business will happen when employees get rid of their inhibitions in using other people's knowledge and the fear of sharing their knowledge to all interested parties. Learning and managing results of this process, known as knowledge management are the essence of the challenges they face in today's new generation.

In literature, we can find that there are five of the following factors that are created in an organization based on knowledge (Baskiewicz 2012, pp. 58-60):

- the requirement of problem and unconventional perception processes in the organization and systematic approach to solving them. The point is that all company employees without exception, were able to lead a deep analysis of the problems to go beyond the simple answers. Solving problems should not preclude continuous self-denial, denial of the selected strategy, the creation of alternative scenarios, examining various solutions, often totally contradictory with the existing;

- experimenting with new ideas. It is understood to gain experience by putting into practice new, often unconventional solutions for which may be specifically understood transformation of knowledge known to us in the knowledge that is deeply understand. In other words, the process may be moving the organization to a higher level of knowledge, which is the transition from descriptive knowledge to explanatory knowledge (to know how something works and to know why it works). In this sense, experimentation in the organization should be treated as a continuous process, which means performing a series of small experiments aimed at the continuous improvement of processes;

- learning from experience. This process requires a systematic review and analysis of past results and achievements of enterprise and storage. This process should be subject to both solutions, which have brought success, as well as those that ended in failure. This allows employees at any time, to reach into existing solutions and experiences, to avoid committing the same mistakes or take advantage of positive experiences to new projects. There is a saying that "a smart man learns from his mistakes, but the smarter man learns from the mistakes of others." These "mistakes of others" is the knowledge base for those searching for success;

- learning from others. To succeed, a company must be open to new values, ideas, technology and the experience of other companies. The aim should be to meet new best practices, patterns of different industries or sectors and adapt them to their own conditions; 
- promoting positive experiences and knowledge in the enterprise. These activities require the use of written and visual reports, visits, organizing training courses and training. Employees with extensive knowledge and skills are transferred to different organizational units in order to be able to share their knowledge.

The processes of acquiring, transforming and passing information are relevant in all of areas mentioned above, considering the pools of data or the directions in which these information flow. For strategic management, probably the most important are information from the environment, because they shape, or even determine the strategic options of the enterprise. For the increase of operationalization or rising effectiveness of internal processes, most important will be information concerning effectiveness of staff, machinery and devices, used management methods or techniques. For the increase of interest in the enterprise, usually reflected in a positive sales dynamic, the most important will be information from the enterprise, directed to its customers, i.e. the market. For an effective process of passing information to take place, the following conditions must be met (Falkowski, Tyszka 2001, pp.22-29):

- the information is passed in a language understood by both parties,

- effective medium of information is applied,

- message remains clear, i.e. unaffected by external factors,

- transmission is reflected,

- the information is intended for the recipient.

The sender transmits in the communication process specific information encoded in a manner understandable to the recipient chosen communication channel. Channels of communication can be: verbal communication and social media, as essential channels for buzz marketing.

\section{Buzz marketing as an effective tool of passing information to the customer}

Having in mind the fact, that the competition is „,not for the products, but for perception" ( Ries, Troutb 1997, p. 12), to reach intended goals, it is necessary to optimize the flow of desired and selected information concerning the enterprise, from the enterprise to its environment, especially its potential customers. The relevance of this process can be highlighted with the words of P.F. Drucker - "the only right definition of business goal is: create customers (Drucker 1994, p. 52)".

Buzz marketing is a modern form of marketing, the concept of which up to recently was based on bringing the marketing information to the receiver through direct verbal communication (Gardner 2005; Gicquel 2006). Besides face-to-face communication, a perfect medium for buzz marketing is the Internet, especially via discussion forums, e-mail, or instant massaging. The new forms of marketing activities rise upon the use of newest information technologies, which create versatile opportunities for information transfer and data exchange during the communication between market participants. The global computer network facilitates the integration of marketing activities, including promotion. Recently, 
also social networking sites like Facebook are being used to pass "confidential" information or advice, thus not only direct discussion or stories are information channels, but computer networks as well (Allen 2009). Internet buzz marketing is not always based on spontaneous customer opinions. More often companies hire specialists, who are responsible for creating opinions on company's products or services. It is also common, that these activities are outsourced to companies specialized in creating positive image of the order-giver (see Agent Buzz (http://agentbuzz.pl), Brandle (http://www.brandle.pl.), among others). It rises the hypothesis, that the activities of buzz marketing may be classified as a part of widely understood public relations.

Buzz marketing is based on positive impressions on the product, service or the enterprise. The profits the customer had motivate him to give positive recommendation to his acquaintances. People are generally more likely to believe positive opinions on products or services they heard from their friends, than from e.g. TV commercials (Sernovitz 2014; Mourdoukoutas, Siomkos 2009).

Buzz marketing is becoming more and more powerful marketing medium, capable of bringing attention to products that no one ever heard before. Spectacular success of products like Harry Potter, foldable scooters, Chrysler PT Cruiser or "Blair Witch" movie are a few examples of recent years. Despite them, still lot of CEO's and marketing managers underestimate buzz marketing and hold on to its popular stereotypes. Renée Dye lists brings down those myths (http://www.hbrp.pl/ redakcja_poleca.php?id=1065\&t=fama-to-dobra-reklama, odczyt: 24 stycznia 2016):

Myth 1. Buzz accompanies only outrageous or edgy products. In fact, buzz can be gained by even the least expected products.

Myth 2. Buzz just happens. In reality it is the effect of well-thought marketing tactics, including "seeding" a vanguard group, ration supplies, use celebrities to generate buzz, leverage the power of ranking lists, and initiating grassroots marketing.

Myth 3. Best customers are the best choice for creating buzz. In fact, often countercultures are great in generating buzz.

Myth 4. Only a fast operating market leader can benefit from buzz. In reality, "copycats" can also benefit on buzz, if they know how to play the game.

Myth 5. Buzz is created through media and advertising. Actually, media and advertising should not be overused, or else there will be not enough time and space for the buzz to fully develop.

Through globalization and international spread of brands, buzz marketing can have a substantial influence on the shape of the market. No doubt that companies with no control of that may soon sadly realize, that buzz marketing has the control over them. Especially, if more often the channel for realization of buzz marketing is the Internet environment, which enables communication with customers while integrating all marketing elements. Moreover, the Internet is a medium of advertising communication reaching the most numerous group of potential customers, enabling long-term contacts with them, while being cost-effective. 


\section{The role of buzz marketing in the process of passing information in an example enterprise based in a rural area}

To identify the role of buzz marketing in the process of passing information from the enterprise to its customers, an empirical research was conducted with the method of a survey ran in a chosen rural area based enterprise. The chosen enterprise is operating for over ten years in a rural community in south-west part of Częstochowa county, with a population of 10500 . The enterprise is providing educational services in the form of teaching foreign languages, for both institutional and individual entities. The institutional customers include three enterprises in Częstochowa and three kindergartens. However, the most important process realized in the analyzed enterprise is organizing and facilitating stationary, 1-year courses. Individual customers use the services in the building located in the center of the community, which is a property of the enterprise. The building consists of 3 classrooms, waiting room, office and sanitary room. Individual customers are aged 4 to 56, although it is worth noting that $80 \%$ of customers consists of schoolchildren. As for today (16 January 2016) the total number of customers is 128 .

The survey was conducted between $11^{\text {th }}$ and $15^{\text {th }}$ January 2016. The respondents consisted of company's students and their parents. To reach a deeper understanding of the phenomenon, the survey was followed-up by an unstructured interview with the enterprise owner.

The research was conducted on 197 respondents; 102 students including 34 girls and 68 boys and 95 parents (Table 1).

Tabela 1. Characteristics of the research sample

\begin{tabular}{|c|c|c|c|}
\hline \multicolumn{4}{|c|}{ Characteristics of the research sample } \\
\hline \multirow{2}{*}{ Students } & Girls & 34 & $17 \%$ \\
\cline { 2 - 4 } & Boys & 68 & $34 \%$ \\
\hline \multirow{2}{*}{ Parents } & Women & 83 & $43 \%$ \\
\cline { 2 - 4 } & Men & 12 & $6 \%$ \\
\hline \multicolumn{2}{|c|}{ Total } & $\mathbf{1 9 7}$ & $\mathbf{1 0 0 \%}$ \\
\hline
\end{tabular}

Source: Own work.

When asked "which of the following factors is most often critical in your decision when you choose school courses?", $87 \%$ of respondents chose the good opinion and recommendation from friends and family, which confirms the hypothesis, that buzz marketing plays a key role in communication processes especially in rural areas. Another important factor was the familiarity and trust in the company's owner, chosen by $67 \%$. It is worth noting that the owner is a native inhabitant and an active member of the local community in which the research took place. Other important factors included kind service (43\%) and the presence of leaflets and brochures informing about realized courses (40\%) (figure 1).

To get more precise information on the relevancy of opinions, the respondents were asked to rate their importance. 95\% of respondents rated opinions on the service quality as "very important". Such high rating also highlight the importance 
of buzz marketing. It is worth noting that most of the course participants are students of one of two local primary schools, one kindergarten and one secondary school (gymnasium). This situation enables better communication between the students themselves and between their parents. Most of these people know each other and it is common to see groups of parents talking to each other after walking their children to school (figure 2).

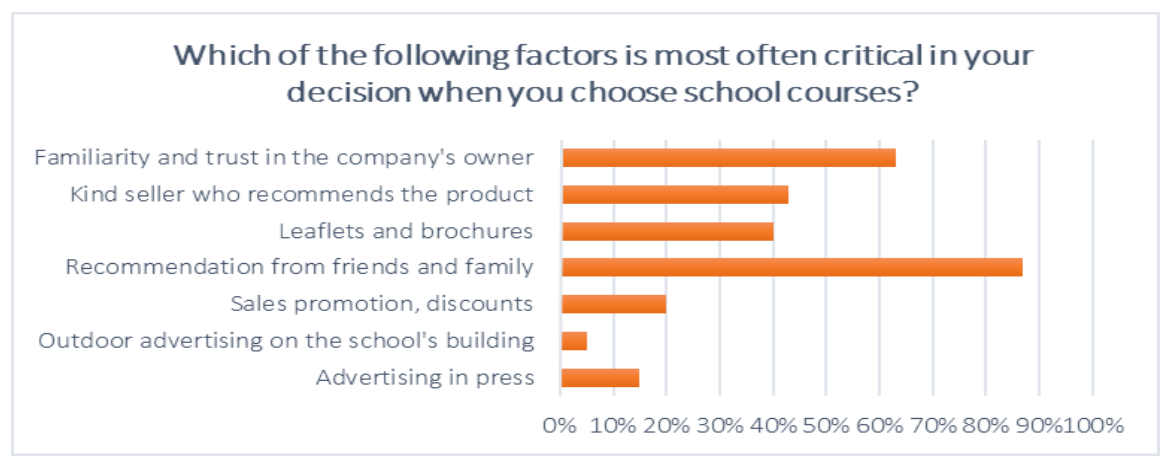

Figure 1. Which of the following factors is most often critical in your decision when you choose school courses?

Source: Own work based on research results.

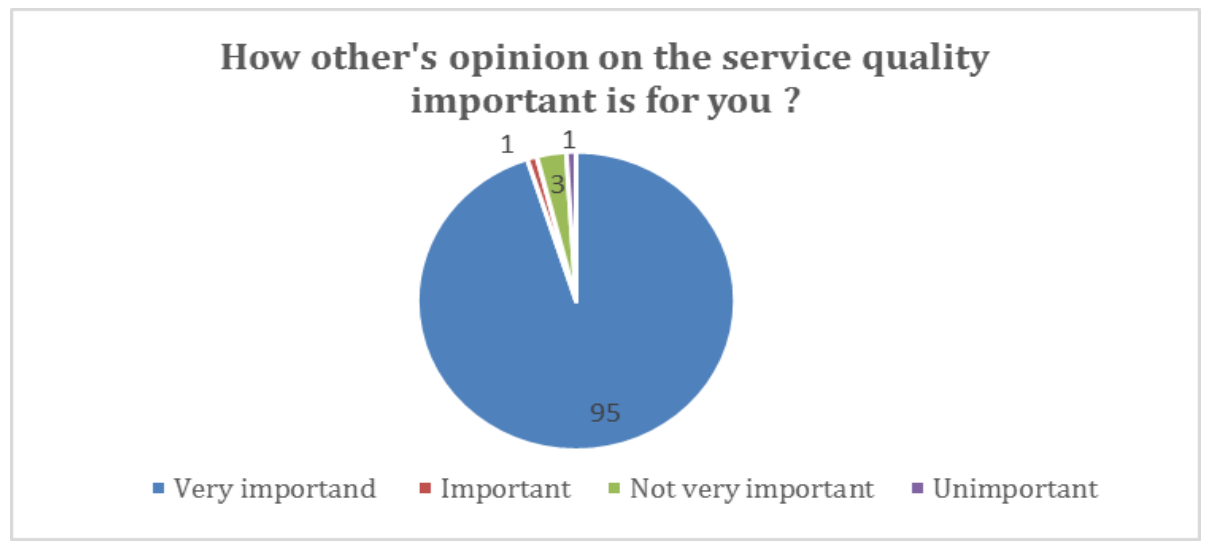

Figure 2. How others's opinionon the serivice quality important is for you?

Source: Own work based on research results.

The results of the research show that almost half of the respondents (45\%) willingly exchange information concerning products or services they use every day. $23 \%$ respondents share this information but not on every meeting, and only $10 \%$ declare they do not exchange their opinions on products or services they use (figure 3 ).

Family is the main source of information concerning company's services, as shown by $78 \%$ of respondents. The second most popular source is a group of friends, chosen by $67 \%$. It is worth noting that family plays a more important 
informative-advisory function than friends. It is interesting, if in large cities, where buzz marketing also plays a vital role, family would also be higher rated than friends? There are evidence suggesting that in urban areas friends take over the role of family, including the informative-advisory function.

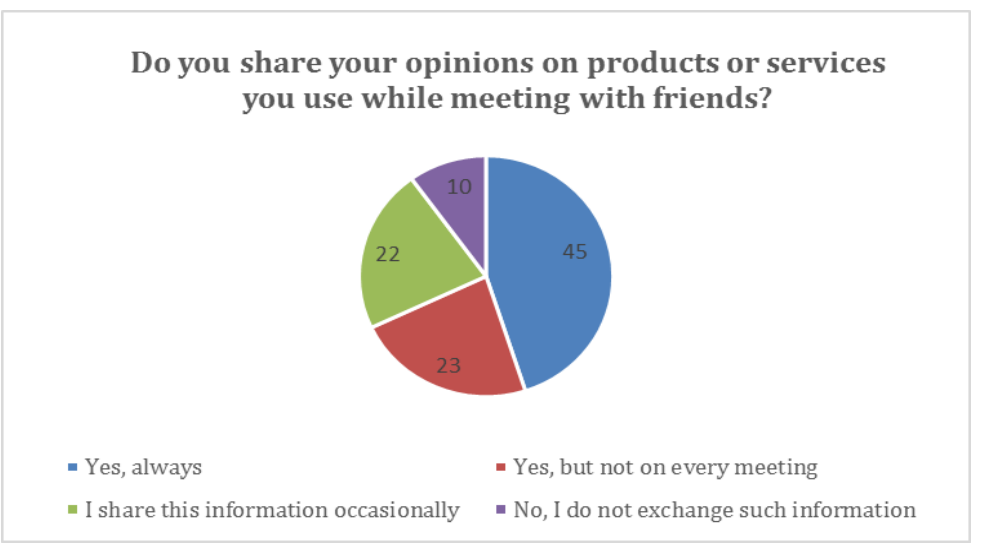

Figure 3. Do you share your opinions on products or services you use while meeting with friends?

Source: Own work based on research results.

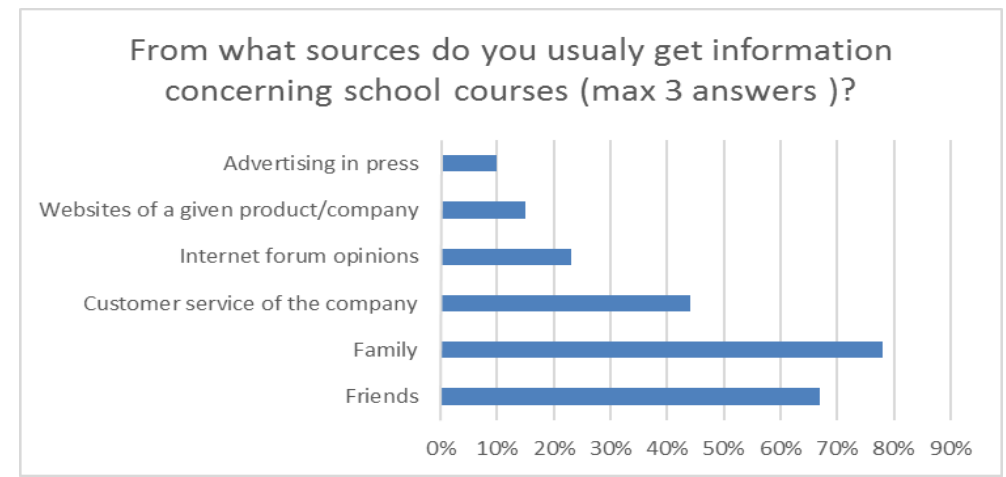

Figure 4. From what sources do you usualy get information concerning school courses (max 3 answers)?

Source: Own work based on research results.

\section{Summary}

The active stimulation of buzz marketing is giving the companies (especially those based in rural areas) new possibilities and chances, which if used correctly, enable not only staying on the market, but also improving the market position, through development, raising the company image. Buzz marketing is shaping the needs and expectations of both society and local community. It contributes to better communication inside the company, and with the market environment, it helps integrate realized market activities. In times when products do not vary in quality 
or price, enterprises race to effectively gain social favor, which in a long term perspective will contribute to a bigger customer base and raised income.

\section{References}

1. Allen K., Viral marketing 100 success secrets: secret strategies, buzz marketing and interactive marketing tips and tricks-- 100 simple online campaign principles. Emereo Publishing 2009.

2. Baskiewicz N., Information as a Factor in the Growth of Competence in Process Units, [in:] Enterprise During Global Market Instability. Edited by A. P. Balcerzak, Polish Economic Society Branch in Toruń, Torun 2012, pp. 58-60.

3. Drucker P.F., Praktyka zarzadzania. AE w Krakowie, 1994, p. 52.

4. Falkowski A., Tyszka T., Psychologia zachowań konsumenckich. Gdańskie Wydawnictwo Psychologiczne, Gdańsk 2001, pp.22-29.

5. Gardner S., Buzz Marketing with Blogs For Dummies, Hoboken, N.J. Chichester, Wiley 2005.

6. Gicquel Y., Le buzz marketing: Le génie des glaciers. Chambéry, 2006.

7. http://agentbuzz.pl.

8. http://www.brandle.pl.

9. http://www.hbrp.pl/redakcja_poleca.php?id=1065\&t=fama-to-dobra-reklama, odczyt: 24 stycznia 2016.

10. http://www.inzynieriawiedzy.pl/wiedza/wiedza-informacje-dane, odczyt: 24 stycznia 2016.

11. Mikuła B., Ćwikliński M., Integracyjna rola zarządzania wiedza. Przegląd Organizacji, nr 4, 2001.

12. Moszkowicz M., Zarzadzanie strategiczne. Systemowa koncepcja biznesu. PWE, Warszawa 2005, p. 312.

13. Mourdoukoutas P.; Siomkos G. J., The Seven Principles of WOM and Buzz Marketing: Crossing the Tipping Point, New York, Springer Oct. 2009.

14. Ries A., Troutb J., 22 niezmienne prawa marketingu. Seria Marketing bez tajemnic. PWE, Warszawa 1997, p. 12.

15. Sarvary M., Knowledge Management and Competition in the Consulting Industry. California Management Review, No. 12, 1999. DOI: 10.2307/41165988.

16. Sernovitz A., Marketing szeptany. Wolters Kluwer Polska, 2014.

17. Stankiewicz M.J., Konkurencyjność przedsiębiorstwa. Budowanie konkurencyjności wczasach globalizacji. Wydawnictwo Dom Organizatora, Toruń 2002, p. 229.

18. Stoner J., Wankel Ch., Kierowanie. PWE, Warszawa 1996, p. 477.

\section{MARKETING SZEPTANY JAKO SKUTECZNE NARZĘDZIE WSPOMAGAJĄCE PROCESY INFORMACYJNE W PRZEDSIĘBIORSTWIE ULOKOWANYM NA OBSZARZE WIEJSKIM}

Streszczenie: Celem niniejszego artykułu jest prezentacja zjawiska marketingu szeptanego, jako skutecznego narzędzia wspomagającego procesy informacyjne w przedsiębiorstwie mającym swą siedzibę na obszarze wiejskim. Sama informacja, zarówno ta wejściowa jak i wyjściowa uznana została jako kluczowy zasób determinujący konkurencyjność przedsiębiorstwa. Biorąc pod uwagę powszechnie uznane i wciąż aktualne standardy zachowań, uznano, iż na obszarach wiejskich w procesie przekazywania informacji z firmy do otoczenia zasadniczą rolę może odgrywać marketing szeptany, co zostało potwierdzone badaniami empirycznymi prowadzonymi metodą ankiety oraz wywiadu swobodnego ukierunkowanego.

Słowa kluczowe: marketing szeptany, informacja, procesy informacyjne, kanały informacyjne 